\title{
SYNERGIC DEVELOPMENT OF ORGANIZATIONS WITH EMPLOYEE
} ASPIRATIONS

Dr. K. R. Subramanian ${ }^{1 *}$

${ }^{*}$ Senior Professor and Business Consultant

\section{*Corresponding Author: -}

\section{Synopsis: -}

Employee involvement in organization development takes place when their aspirations are fulfilled through work. Even with a carefully planned compensation and incentive program the attrition rate in some organizations is high. When management genuinely takes care of employee aspirations the resultant synergy is reflected in customer satisfaction and product quality. Managing employee aspirations takes genuine interest and requires a structure to help employees and plan for their development by Assessment, alignment with business needs and taking steps for development of people. Organizations can help employees sharpen and develop their key skills and values and provide important feedback information to reshape their goals in alignment with the business needs of the organization. Organizational barriers to growth and Professional development of employees leads to lack of commitment and eventual separation of employees. This paper explores such barriers to employee involvement and how synergic development can take place.

Key words: Employee aspirations, organizational barriers, synergic development

\section{(c) (\$) (1)}




\section{INTRODUCTION}

Management of employee aspirations is very much related to Maslow's Hierarchy of Needs in which self-actualization is recognized as the highest need of individual aspiration in his life. Self-actualization simply means being the best you can be at what you do. From an organizational point of view, shortage of critical skills can pose a genuine problem. Actually, $61 \%$ of respondents in the January 2015 Bayt.com Skills and Hiring Trends in the MENA poll have agreed that their company suffers from a lack of skills. Managing employee aspirations effectively is a key driver of growth for both employees and the company.

There is a major distinction between Career Growth and Career Development. In fact, career growth depends on career development. Growth is your organization's ladder to rise. While a ladder (career path) displays only vertical movement between jobs, a career lattice, by contrast, contains both vertical and lateral movement between jobs and would reflect more realistically the career paths of employees in the modern work environment. The ladder is an outdated model of career growth. The lattice is the more appropriate path today.

Career development includes everything employees do to enhance or develop their career advancement and growth. Professionals need solid credentials to instill trust in customers, but also must continuously update and improve those credentials through organizational experience, training and development. Employees have just as much ambition to take on new responsibilities as do other coworkers and competitor groups. Financial benefits (increased revenue from new clients) accrue when your professional employees become known as "go to" people. So organizations should implement a clear program to boost Employee expertise and management skills.

As indicated clearly by the Exhibit 1, given below, barriers to employee growth and development start with poor management and lack of opportunities and other factors at work. This clearly illustrates how and why management should take an interest in employee development through fulfilling their aspirations.

\section{Barriers to professional growth}

- The top two barriers to professional growth were poor management within the company (46\%) and a lack of growth opportunities (45\%).

- Over one quarter of respondents (27\%) also reported favoritism in the workplace as a barrier, and one fifth reported a lack of training opportunities $(21 \%)$, and a disconnect between educational qualification and current job $(21 \%)$ as barriers to professional growth.

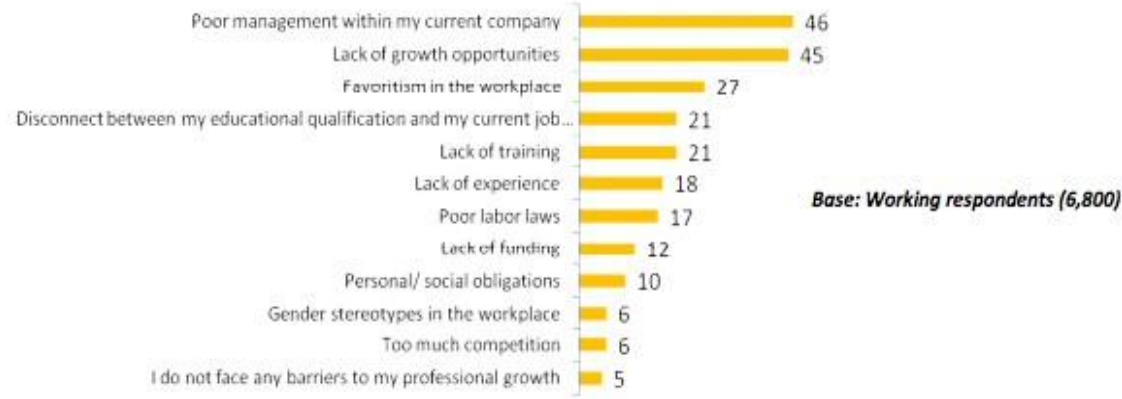

\section{Exhibit 1: Bayt.com Career Aspirations in the Middle East and North Africa Survey - January 2015 (Image credit: Bayt.com)}

\section{OBJECTIVES AND METHODOLOGY}

That there should be congruence between employee expectations and organizational needs do not require any more emphasis as it is well known. The question remains as to how this is achieved by organizations. Employees of organizations wish to contribute to not only to their personal growth but also to the organization development and growth. Their aspirations are humane and if they can be synergized with organizational purpose and greater objectives of social responsibility, there will be a healthy development all round. This paper will investigate the scope of such synergic development of organizations with the specific objectives as:

1. A critical review of current state of organizations.

2. Employee motivations in today's organizations

3. How synergic development can take place

4. Futuristic needs of Organizational development.

5. How do organizations cope with such pressures?

6. Suggestions and recommendation

There has been no dearth of literature on organizational development. Most of them are theoretical expositions. This paper would explore the current state of organizations and future scope for them to develop and meet challenges. Considering the availability of the volume of literature and research studies in related areas it was found sufficient to do a detailed desk research to unearth findings from previous research and arrive at conclusions and suggest ways and means of improving the situation. 


\section{REVIEW OF LITERATURE}

Knowing employees' aspirations is the first step towards successful development and management of Organizations. These aspirations may be related to where they are headed in their professional life, such as wanting a promotion or a salary increase, or personal goals, such as how they plan to maintain their work-life balance. Once they know what they want to achieve in life, you can help them convert these aspirations into more specific, measurable and time-bound goals. Data from the Bayt.com Career Aspirations in the MENA survey shows that while $68 \%$ of professionals in the MENA say they have set professional goals for themselves, $22 \%$ have not set any goals. The latter are specifically the ones who will need help in defining short- and long- term goals.

Employee involvement is creating an environment in which people have an impact on decisions and actions that impact on aspirations on their jobs. It is a management and leadership philosophy about how people are most enabled to contribute to continuous improvement and the ongoing success of their work organization. This involvement increases ownership and commitment, retains your best employees, and fosters an environment in which people are motivated and contribute to achievement of organizational goals. How to involve employees in decision making and continuous improvement activities is the strategic aspect of involvement and can include such methods as suggestion systems, manufacturing cells, work teams, continuous improvement meetings, Kaizen (continuous improvement) events, corrective action processes and periodic discussions with the supervisor. Intrinsic to most employee involvement processes is training in team effectiveness, communication, and problem solving; the development of reward and recognition systems; and frequently, the sharing of gains made through employee involvement efforts.

Employee Involvement is the direct participation of staff to help an organization fulfill its mission and meet its objectives by applying their own ideas, expertise, and efforts towards solving problems and making decisions. From this definition, participation can include representative participation, direct communication, and upward problem solving. We will focus on the latter two categories because this article is more about understanding outcomes, tools, and methods.

\section{Employee Involvement Model}

Increasing the level of employee involvement is situational. The amount of employee involvement depends on: the person's skills and experience, their knowledge of the factors that affect their job and decision making, and the degree to which they understand how their job is connected to other processes within the organization. You can effectively involve employees in decision-making about their jobs. These degrees of involvement tell you how.

Tannenbaum and Schmidt (1958) and Sadler (1970 model (TSSL) provides a continuum for leadership and involvement that includes an increasing role for employees for which they aspire and a decreasing role for supervisors in the decision process. The continuum includes this progression. The supervisor provides complete direction. TSSL is useful when communicating about safety issues, government regulations and for decisions that neither require nor ask for employee input. The supervisor makes the decision and then gains commitment from staff by selling the positive aspects of the decision. TSSL is useful when employee commitment is needed, but the decision is not open to employee influence. The supervisor invites input into a decision while retaining authority to make the final decision herself. The key to a successful consultation is to inform employees, on the front end of the discussion, that their input is needed, but that the supervisor is retaining the authority to make the final decision. This is the level of involvement that can create employee dissatisfaction most readily when this is not clear to the people providing input. The supervisor invites employees to make the decision with the supervisor. The supervisor considers his voice equal in the decision process. The key to a successful decision is when the supervisor truly builds consensus around a decision and is willing to keep his/her influence equal to that of the others providing inputs.

Outcomes of Employee Involvement

Providing opportunities for active participation is beneficial for individuals as well as entire organizations. Applied organizational researchers have identified a myriad of positive outcomes of employee involvement initiatives. The list below shows just how much of an impact that employee participation and voice can have on the performance and wellbeing of a person, team, department, or entire organization.

- Improved organizational decision-making capability (Apostolou, 2000)

- Improved Attitude regarding work (Leana, Ahlbrandt, \& Murrell, 1992)

- Substantially improved employee well-being (Freeman \& Kleiner, 2005)

- Reduced costs through elimination of waste and reduced product cycle times

- (Apostolou, 2000)

- Empowerment, job satisfaction, creativity, commitment, and motivation, as well as intent to stay (Apostolou, 2000; Light, 2004)

- Increased employee productivity across industries (Jones, Kalmi, \& Kauhanen, 2010)

\section{How to Get Employee Involvement}

In order for an employee involvement process to be effective, three things need to be present:

1. Employees need to be given the authority to participate in substantial decision making.

2. Employees need to have training or experience with appropriate decisionmaking skills 
3. Incentives to participate (either implicit or explicit) must be present Formal interventions usually involve manager and staff training, buy-in and vocal support from the highest levels, and the application of specific measures to increase employee participation.

Examples of specific measures include: self-directed/self-managed work teams, problem solving teams, and crossfunctional task-forces (to name a few). However, if you would like to start encouraging employee involvement in your organization right now, try following these steps:

1. Give a brief survey to your staff that is made up of open-ended questions that ask for specific improvement ideas,

2. Review every response,

3. Communicate the results with all of your staff, and

4. Create a team to implement the easiest ideas that can have the greatest positive impact (see this chart as an easy template to organize ideas).

\title{
Factors to increase motivation at work
}

\author{
- Three-fifths of respondents reported that higher salaries and perks/benefits would increase motivation at work. \\ - Interestingly, more respondents stated that opportunities to express creativity (47\%), and work-life balance (45\%) would
} increase motivation, as compared to being promoted to the next level (40\%).

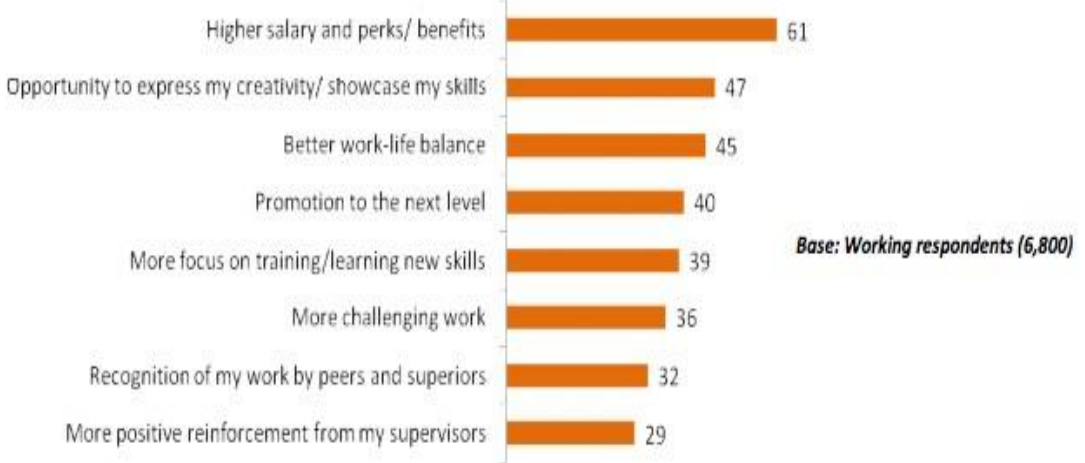
Exhibit 2: Bayt.com Career Aspirations in the Middle East and North Africa Survey - January 2015. Image
credit: Bayt.com

Once the aspirations have been defined and quantified, all that is left is finding ways to achieve them. For aspiration management to be effective, employees' goals need to be aligned with organizational goals. Providing the necessary training is the key to achieving this alignment of goals. Across the MENA (Middle East Nations), $45 \%$ of professionals cite the lack of training and growth opportunities as the main barrier to their personal career growth. Fortunately, investment in training is projected to increase in 2015 according to $73 \%$ of respondents in the Bayt.com Skills and Hiring Trends in the MENA poll.

Employee engagement has three related components: a cognitive, an emotional, and a behavioral aspect. The cognitive aspect of employee engagement concerns employees' beliefs about the organization, its leaders, and working conditions. The emotional aspect concerns how employees feel about each of those three factors and whether they have positive or negative attitudes toward the organization and its leaders. The behavioral aspect of employee engagement is the valueadded component for the organization and consists of the discretionary effort engaged employees bring to their work in the form of extra time, brainpower and energy devoted to the task and the firm. Recent research suggests that highinvolvement work practices can develop the positive beliefs and attitudes associated with employee engagement, and that these practices can generate the kinds of discretionary behaviors that lead to enhanced performance. The section immediately below describes high- involvement work practices and how they are utilized in both manufacturing and service settings. The next section outlines the evidence for the effectiveness of these practices. The final section discusses the implementation process and argues for the importance of embracing a participatory philosophy in order to align the process with the concept of high involvement.

\section{How effective are high-involvement work practices?}

Evidence of the effectiveness of high-involvement work practices has been documented in several research studies. The multivariate statistical analyses conducted on the research data include statistical controls for a variety of factors existing in the environment in order to rule them out as plausible alternative explanations for the findings. As a result, fairly strong inferences can be drawn regarding the impact of the high-involvement management system. The results of this research are impressive. The early research examined the impact of high- involvement work systems in manufacturing organizations. The development of the Saturn Corporation within General Motors constituted a demonstration project for, 
"a radically new organizational form in which work would be organized into teams, work rules would be drastically simplified, and the union would be a full partner in decision making from the bottom to the top of the organization." The project has been largely considered a success. For instance, the J. D. Power and Associates statistics on customer satisfaction showed that in 1992 and every year since, Saturn has led all U.S. car lines and all brands worldwide except for Lexus and Infiniti (Acura and Mercedes in 1997 only) in ratings of vehicle quality, reliability and satisfaction.

Researchers and academicians have examined the implementation of the Modern Operating Agreement (MOA) between the Chrysler Corporation and the United

Automobile Workers (UAW), which was signed and ratified in six Chrysler plants by 1987. The MOA reduced job classifications, tied pay to skills within those classifications, established joint consultation committees, and reorganized work into shop-floor teams. A survey company contacted 782 unionized production workers at their homes 5-6 years after the signing of the MOA contracts. Sixty-four percent of those contacted stated they were satisfied or very satisfied with the MOA, 68\% agreed or strongly agreed that they preferred the MOA to the previous system, and 76\% agreed or strongly agreed that they preferred the team system to the old system.

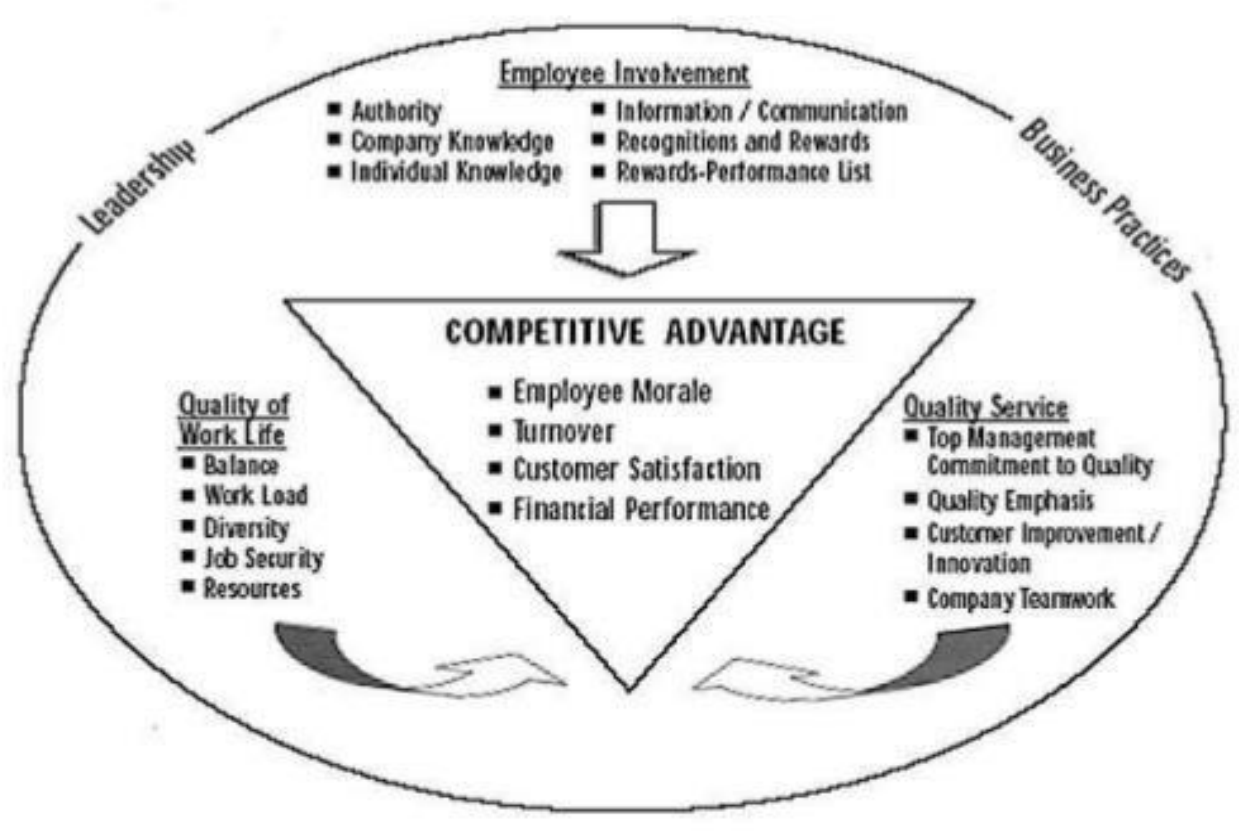

Exhibit 3: Employee Involvement in work

In another study, Eileen Appelbaum and her colleagues (2000) studied 15 steel mills, 17 apparel manufacturers, and 10 electronic instrument and imaging equipment producers. Their purpose was to compare traditional production systems with flexible high performance production systems involving teams, training, and incentive pay systems. In all three industries, the plants utilizing high involvement practices showed superior performance. In addition, workers in the highinvolvement plants showed more positive attitudes, including trust, organizational commitment and intrinsic enjoyment of the work.

Larger studies have confirmed the positive effects of high-involvement work practices in manufacturing. Jeffrey Arthur's 1994 study of 30 steel mini mills in the U.S. in 1988-89 showed that the mills with commitment systems involving more employees training and more employee participation in solving production problems had higher productivity, lower scrap rates, and lower employee turnover. John Paul MacDuffie's 1995 study of an international database examining 62 automobile assembly plants in 1989-90 found that flexible production plants with high-involvement practices such as team-based work systems, contingent compensation, and extensive employee training consistently outperformed traditional plants in terms of both productivity (labor hours per vehicle) and quality. In 2005, Deepak Datta and his colleagues analyzed survey responses from 132

U.S. manufacturing firms and found that firms utilizing high-performance work systems showed significantly higher labor productivity than their competitors.

More recent researchers have asked the question of whether high-involvement work practices can be generalized to the service industry sector. Once again, impressive results have been documented. Two studies of employees in the life insurance industry examined the impact of employee perceptions that they had the power to make decisions, sufficient knowledge and information to do the job effectively, and rewards for high performance. Both studies included large samples of employees (3,570 employees in 49 organizations and 4,828 employees in 92 organizations). In both studies, 
high-involvement management practices were positively associated with employee morale, employee retention, and Company financial performance.

Another recent study has tested high-involvement work practices in a call center environment. In a field experiment, 149 call center employees were randomly assigned to either high involvement work practices, autonomous teams, aligned job design (essentially new performance metrics aligned with the business strategy), or the traditional management system. Findings comparing pre- and post test scores showed substantial improvement in organizational commitment and intrinsic job satisfaction in the high-involvement work practices group compared to no change for the control group or the autonomous work team group, and impact on organizational commitment only for the aligned job design group. The highinvolvement work practice group also showed the most improvement in performance on a variety of measures.

\section{ANALYSIS AND CONCLUSION}

A critical review of current organizations reveals that they are in a flux. The reasons can be many; but one of the most influential factors is the dynamic nature of business environment in which these organizations operate today. Orgnizations are aware of the fact that employee participation in their progress is vital, and they have come a long way from appreciating Maslow's hierarchy of needs to self-actualization needs of individuals in organizations. Today, organizations have understood the value of individual contributions from every employee to career growth and development needs of individuals. Organizations today constantly endeavor to understand what motivates an employee to stay with them and contribute!

Though many initial surveys of employee motivation and commitment revealed that higher salaries and perks propel them to make a contribution, it is becoming increasingly clear that it is not enough. Employees want to get more and more involved with the company so they can make the company grow and take it to a different level and get recognition and reward for the same. Performance based rewards and industry standing make them happy. Employer and employees have realized that growth is possible only when their mutual aspirations are synergized to propel the company to new heights.

More and more companies ensure employee involvement by giving them more authority to make decisions at selfmanaged team level. With more involvement synergic development of company takes place. Commitment to Quality, better business leadership and company performance is ensured. Employee engagement in and behavioral aspects are ensured through participation. The cognitive employee engagement improves employees' beliefs about the organization, its leaders, and working conditions. The emotional aspect reinforces their confidence in the organization to take care of their needs and this consists of the discretionary effort that employees bring to their work in the form of extra time, brainpower and energy devoted to the task and the firm.

The futuristic needs point towards development of further employee engagement and involvement to the level of selfmanaged teams with least amount or nil direction and control. When the organizational intervention needs are reduced, self-motivated teams working well like greased machinery emerge. This will be the future scenario.

This indeed is a challenge to present and future management teams. Synergy between Employee Aspirations and organizational expectations and commitment to fulfill them alone will take them forward.

\section{RECOMMENDATION}

Academic Researchers and industry practitioners have done a lot of ground work to understand the organizational dynamics and this will help them design the futuristic organizations. Continuous monitoring of Business environment and the needs of the industry will help them take their organizations forward!

\section{REFERENCES}

[1].Tannenbaum, R. and Schmidt, W. "How to choose a leadership pattern". Harvard Business Review, 1958, 36, 95-101.

[2].Beck, Joseph \& Susan, TQM: Implementing Continuous Improvement, Sterling Publishing Co, New York, 1993.

[3].Bounds, Gregory, Dobbins, Gregory and Fowler, Oscar, Management: A Total Quality Perspective, International Thomson Publishing, Ohio, 1995.

[4].George, Stephen \& Weimerskirch, Arnold, Total Quality Management, John Willey \& Sons, New York, 1994.

[5].Hradesky, Jack, Total Quality Management Handbook, Mc-Graw Hill, New York, 1995.

[6].Noori, Hamid \& Radford, Russell, Production and Operations Management, McGraw Hill, New York, 1995.

[7].Pike, John \& Barnes, Richard, TQM in Action, Chapman \& Hall, London, 1994.

[8].Ryan, Joe, Giving people the chance to sparkle, People Management, June, 1998, p.p. 40-42

[9].Edwinah Amah, Augustine Ahiauzu, (2013) "Employee involvement and organizational effectiveness", Journal of Management Development, Vol. 32 Issue: 7, pp.661 - 674

[10]. Alison M. Konrad (March/April 2006) , "Engaging employees through highinvolvement work practices" , IVEY Business Journal

[11]. Rashi Saxena, International Journal of Science Technology \& Management, Volume No.04, Special Issue No.02, February 2015

[12]. Rao V S P, Human Resource Management text and cases, Excel Books, 2009, $2^{\text {nd }}$ Edition.

[13]. Aswathapa K, Human Resource Management, McGraw Hill Companies, 2008, $5^{\text {th }}$ Edition

[14]. Greenberg J. \& Baron R, Behavior in Organisations, Pearson Education, 2009, $9^{\text {th }}$ Edition 
[15]. Robbins, Stephen P, Judge T. A, Organizational Behavior, Pearson Education, 2009, $12^{\text {th }}$ Edition

[16]. Evancevich J. M, Human Resource Management, McGraw Hill company, 2007, $7^{\text {th }}$ Edition

[17]. Dessler G, Human Resource Management, Prentice-Hall Inc, 2008, 11thEdition

[18]. J.L. Cotton, Employee Involvement - Methods for improving Performance and work attitude (Newbury Park CA: Sage Publication 1993) pp 129-130, 139-140.

[19]. Heslin, P. A., Vandewalle, D., \& Latham, G. P. (2006). Keen to help? Managers' implicit person theories and their subsequent employee coaching. Personnel Psychology, 59(4), 871-902.

[20]. Latham, G. P., Borgogni, L., \& Petitta, L. (2008). Goal setting and performance management in the public sector. International Public Management Journal, 11(4), 385-403.

[21]. Meyer, J. P., Becker, T. E., \& Vandenberghe, C. (2004). Employee commitment and motivation: conceptual analysis and integrative model. Journal of Applied Psychology, 89(6), 991.

[22]. Moorman, R. H., Niehoff, B. P., \& Organ, D. W. (1993). Treating employees fairly and organizational citizenship behavior: Sorting the effects of job satisfaction, organizational commitment, and procedural justice. Employee Responsibilities and Rights Journal, 6(3),

[23]. Ogundele, J, A (2012). Organizational commitment, and procedural justice International Public Management Journal, 11(4), 385-403

[24]. Robbins, N .G., \& Judge, J. E., (1998 ). Influence of top management on employee commitment. Journal of applied psychology, 78 (2), 151-156.

[25]. Selen, D, L. (2000) employee commitment and Industrial Management, 7(8), 1820.

[26]. Apospori, E., Nikandrou, I., Brewster, C., \& Papalexandris, N. (2008). HRM and organizational performance in northern and southern Europe. The International Journal of Human Resource Management, 19(7), 1187-1207.

[27]. Bassanini \& Scarpetta, (2002). Performance management and commitment: European journal of operational research, 181(1), 453-467.

[28]. Bragg, T. (2002). Improve employee commitment. Industrial Management, 7(8), 18-20.

[29]. Brewster,N..\& Papalexandris, (2008). Social responsibility and employee commitment. Business Ethics: A European Review, 16(1),

[30]. Briscoe, D. R., \& Claus, L. (2008). Employee performance management: policies and practices in multinational enterprises. Performance Management Systems: A Global Perspective, Routledge, London, 15-39.

[31]. Collier, J., \& Esteban, R. (2007). Corporate social responsibility and employee commitment. Business Ethics: A European Review, 16(1), 19-33.

[32]. Dolan, S. L., Tzafrir, S. S., \& Baruch, Y. (2005). Testing the causal relationships between procedural justice, trust and organizational citizenship behavior. Revue de gestion des resources humaines, 57, 79-89.

[33]. Fowler, J. (1990). Evaluating that piece of paper: the effect of motivation and certification status on occupational commitment. Journal of leadership \& organizational studies, 18(1), 39-45

[34]. Grant, A.M. (2008). Giving commitment: Employee support programs and prosocial sneaking process. Academy of management journal, 51(5), 898-918

[35]. Gul, Ahmad Locke, E. A., \& Latham, G. P. (2002). Building a practically useful theory of goal setting and task motivation: A 35-year odyssey. American psychologist, 57(9), 705.

[36]. Lockett, J. (1992). Effective Performance Management: A strategic guide to getting the best from people: Kogan Page.115.

[37]. Pradhan \& Chaudhury (2012), performance management in the public sector. International Public Management Journal, 11(4), 385-403.

[38]. Rayton, B. A. (2006). Examining the interconnection of job satisfaction and organizational commitment. The International Journal of Human Resource Management, 17(1), 139-154.

[39]. Robbins, N .G. \& Judge, J. E., (1998). Influence of top management on employee commitment. Journal of applied psychology, 78 (2), 151-156.

[40]. Selen, D, L. (2000) employee commitment and Industrial Management, 7(8), 1820.

[41]. Stavrou, E. T., Charalambous, C., \& Spiliotis, S. (2007). Human resource management and performance: A neural network analysis. European journal of operational research, 181(1), 453-467.

[42]. Tzafrir, \& Baruch, (2005) training and development in relation to performance. European journal of operational research,236-290

[43]. Youndt, M. A., \& Snell, S. A. (2004). Human resource configurations, intellectual capital, and organizational performance. Journal of Managerial Issues, 337-360.

[44]. Flynn, B.B., Schroeder, R.G., Sakakibara, S. 1995. "The impact of quality management practices on performance and competitive advantage", Decision Sciences, Vol. 26 pp.659-91

[45]. Boldman, L. G \& Deal, T. E. (2003), Reframing Organization: Artistry, Choice, and Leadership,3rd Edition, JosseyBass Press, San Francisco, U.S.

[46]. Ford, L. (2005, Transform your workplace: 52 proven strategies to motivate, energize, and kick productivity up to the next level, Mc Graw Hill, New York, U.S

[47]. Kamalian, A. R., Yaghoubi, N. M., \& Moloudi, J., (2010) Survey of Relationship between Organizational Justice and Empowerment (A Case Study).European Journal of Economics, Finance and Administrative Sciences, 24, 165171.

[48]. McGregor, D \& Cutcher-Gershenfeld, J. (2006). The human side of enterprise, annotated edition. New York: McGraw Hill. 
[49]. Tietjen, M. A. \& Myers, R. M. (1998) Motivation and job satisfaction, Management Decision, vol. 36, no 4, pp. 226-231

[50]. Zammuto, R. F., (1982). Assessing Organizational Effectiveness, State University of New York Press, Albany, NY.

\section{Web references}

1. www.incentivecentral.org/pdf/employee_engagement_study.pdf

2. www.berr.bov.uk/file52215.pdf

3. www.mckinseyquarterly.com/Organization/Change_Management/What_succes sfu_transforamtions_share_McKinsey_Global_Survey_resutls_2550 